\title{
Leituras de Clausewitz no Exército brasileiro: interpretações da trindade da guerra
}

\author{
Reads of Clausewitz in brazilian army: war's trinity interpretations
}

\author{
Carla Cristina Wrbieta Ferezin \\ Doutoranda em Ciência Política \\ Universidade Federal de São Carlos - UFSCar \\ e-mail: carlaferezin@gmail.com
}

Recebido: 05/05/2013

Aceito: 01/07/2013

\begin{abstract}
RESUMO Clausewitz é um dos maiores teóricos de guerra e estratégia, desde o século XIX suas obras são lidas e citadas, sobretudo no meio militar. Contudo, ainda desconhecemos a apropriação de Clausewitz entre os militares brasileiros. Assim, o objetivo central deste artigo é analisar, através da análise do discurso, as leituras efetuadas no Brasil sobre a teoria clausewitziana, focando o conceito central deste autor: a trindade da guerra. O corpus da pesquisa foram os artigos publicados "A Defesa Nacional", no período do pós-Guerra Fria, quando ocorria um intenso debate mundial sobre a atualidade ou obsolescência de Clausewitz para os conflitos dos séculos XX e XXI. Elencamos algumas interpretações da trindade entre os militares brasileiros, que a utilizaram para defender ou criticar a contemporaneidade do autor.
\end{abstract}

Palavras-Chave Clausewitz; Pensamento militar; Exército brasileiro; Trindade da guerra.

ABSTRACT Clausewitz is one of the greatest theorists of war and strategy, since the century XIX your works are read and cited, especially in the military field. However, we still don't know the Clausewitz appropriation among the Brazilian army members. Thus, the main objective of this paper is analyse, through the speech analysis, the readings taken on Brazil about the clausewitzian's theory, focusing on this author's main concept: the war's trinity. The corpus of this research was the published articles in "A Defesa Nacional" (The National Defense), on post-Cold War period, when an intense global debate was happening about the current affairs or obsolescence of Clausewitz to the conflicts of $X X$ and XXI centuries. We list some trinity interpretations among Brazilian army members, which use these interpretations to defend or criticize the author's contemporaneity.

KEYWORDS Clausewitz; Military thought; Brazilian army; War's trinity. 


\section{Introdução ${ }^{1}$}

O general Carl Philipp Gottlieb von Clausewitz (1780-1831) é considerado um dos principais teóricos do período de formação do pensamento militar moderno. Suas concepções nos proporcionaram as primeiras reflexões da guerra como um instrumento da política de Estado, a partir de suas experiências com as guerras da Revolução Francesa e com Napoleão Bonaparte (1769-1821). O general prussiano é um dos pensadores estratégicos mais "lidos" e apropriados nas instituições militares ocidentais desde o século XIX, mantendo-se como leitura essencial nos séculos posteriores. Contudo, a "descoberta" de Clausewitz trouxe distintas apropriações de suas concepções, demonstrando que muitos de seus leitores distorceram o real significado de sua teoria. As preocupações inerentes ao contexto histórico e as interpretações pessoais de cada leitor parecem ter tido impacto significativo sobre as diferentes (positivas e negativas) imagens que Clausewitz recebeu ao longo do tempo, eis a hipótese central que guia este artigo. As conjunturas de conflitos (Primeira e Segunda Guerras Mundiais e Guerra Fria) disseminaram "a todo vapor" a teoria clausewitziana, o que proporcionou distintas leituras e interpretações acerca da validade e atualidade da obra maior de Clausewitz, Da Guerra.

No Brasil, Clausewitz também despertou a atenção, sobretudo, no período do pós-Guerra Fria, quando a concepção da trindade da guerra promovia a "ressurreição" da teoria clausewitziana em diversos países ocidentais. Nesse quadro, propõe-se investigar a interpretação que os militares brasileiros deram a famosa trindade da guerra, tentando evidenciar como a conjuntura (interna e externa) do pós-Guerra Fria influenciou uma apropriação diferenciada (e muitas vezes equivocada) da trindade proposta por Clausewitz. Após levantamento bibliográfico aponta-se à ausência de estudos destinados a compreender a influência que a teoria clausewitziana teve no Brasil, assim, pretende-se preencher uma lacuna importante na área estratégica e política do país. ${ }^{2}$ Para alcançar o objetivo supracitado recorrer-se-á a análise de um importante periódico militar brasileiro: A Defesa Nacional. A escolha de tal periódico deu-se devido à estreita relação de seus fundadores, os Jovens Turcos, com o

\footnotetext{
${ }^{1}$ Este artigo faz parte da dissertação de mestrado da autora, intitulada "A Recepção de Clausewitz no Exército Brasileiro: da Guerra Fria ao pós-Guerra Fria” (2012), sob orientação do Prof. Dr. João Roberto Martins Filho e financiada (bolsista) pela Fundação de Amparo à Pesquisa do Estado de São Paulo - FAPESP.

2 A influência das ideias de Clausewitz em outros países, no entanto, é produtiva e nos fornece um importante referencial bibliográfico. Ressalta-se aqui o trabalho de Bassford (1994) ao investigar a recepção da teoria clausewitziana na Inglaterra e América do Norte.
}

Exército alemão no século XX. Acreditamos que os Turcos em seu estágio na Alemanha, entre os anos de 1905 a 1912, sofreram influência das leituras então dominantes do pensamento teórico de Clausewitz no Exército alemão, e provavelmente esse influxo repercutiu na revista A Defesa Nacional.

Este artigo é de cunho exploratório e é delineado, basicamente, por pesquisa bibliográfica e documental. Buscamos, em um primeiro momento, a literatura sobre a recepção das ideias de Clausewitz em alguns países ocidentais, tentando compreender como se deu a disseminação e aceitação de sua teoria ao longo do tempo. Para buscar a influência de Clausewitz no Brasil, optamos pelo periódico militar, A Defesa Nacional. Ressalta-se aqui a pouca importância que os periódicos militares têm entre os pesquisadores da área acadêmica, poucos trabalhos procuraram destacar o importante papel que essas revistas têm para a compreensão do discurso militar. De vertente qualitativa este trabalho adotou a análise do discurso como procedimento metodológico, a fim de tentar evidenciar como o contexto histórico-social influencia na produção discursiva do sujeito, mas como também o sujeito possui lado ativo e criativo na construção do discurso.

Feita esta introdução, apresentaremos uma concisa história da vida e do progresso intelectual de Clausewitz, na tentativa de evidenciar como a sua experiência militar influiu decisivamente na formulação de sua teoria da guerra. Em seguida, abordaremos alguns leitores de Clausewitz, assinalando as distintas leituras acerca deste autor. Tentar-se-á demonstrar como as interpretações sobre a teoria clausewitziana modificaram-se significativamente em conjunturas de conflito. Posteriormente, será focado o debate mais contemporâneo sobre a atualidade da teoria clausewitziana no pós-Guerra Fria. Ao final, abrangeremos as leituras e interpretações que os militares pertencentes ao Exército brasileiro deram ao conceito de trindade da guerra, elemento chave na discussão sobre a relevância (ou não) de Clausewitz para o século XXI.

\section{Clausewitz, Trajetória Militar e Intelectual}

Clausewitz foi um soldado profissional a partir dos seus doze anos de idade e enfrentou a sua primeira batalha logo aos treze anos, quando presenciou a ruína do Exército prussiano (1794) frente ao Exército revolucionário de Napoleão. Logo no início de sua carreira, como oficial, serviu diretamente ao reformador do Exército prussiano, o general Gerhard Scharnhorst (1755-1813) e logo depois a outro reformador militar, o general August von 
Gneisenau (1760-1831). Scharnhorst, sobretudo, teve papel central na evolução intelectual de Clausewitz, iniciando-o na carreira literária. Scharnhorst indicou Clausewitz ao editor do mais importante jornal militar da Alemanha, e em 1805 ele escreveu seu primeiro artigo, no qual refutava as teorias estratégicas do alemão Heinrich Dietrich von Büllow (1757-1807), o mais famoso intérprete das guerras napoleônicas naquele ano.

Clausewitz o criticava a partir de três pontos: a definição de Büllow sobre estratégia e tática; a desconsideração dos efeitos psicológicos no combate armado e o cerceamento da teoria estratégica a partir, somente, da análise de elementos matemáticos e geográficos (Aron, 1976). Clausewitz tinha a convicção de que a teoria de Büllow era limitada, pois não elencava todos os elementos possíveis para o entendimento da guerra (Paret, 2001). O general prussiano não tolerava a certeza que Büllow quis dar à guerra. Em sua visão, a guerra era mais do que cálculos e probabilidades, esta "[...] colocava em jogo sorte e forças morais, criando assim suas próprias possibilidades [...]" (Strachan, 2008: 56). Mais tarde, Clausewitz também desferiu críticas a outro teórico estratégico que também pensou a guerra sob o prisma da certeza, da imutabilidade, o general franco-suíço Antoine-Henri Jomini (1779-1869).

As críticas empreendidas por Clausewitz a Jomini foram publicadas depois da morte do general alemão, em 1833. Em 1838, Jomini devolveu as críticas:

Clausewitz tinha uma pena ágil, mas essa pena, por vezes um pouco teimosa, é pretensiosa demais para uma discussão didática, em que simplicidade e clareza devem ser a primeira exigência. Mais que isso, o autor se revela um tanto cético em relação à ciência militar: seu primeiro volume não passa de uma explosão contra toda a teoria da guerra, ao passo que os dois seguintes, cheios de máximas teóricas, provam que o autor acredita na eficácia de suas próprias doutrinas, mesmo que não acredite na dos outros. Quanto a mim, afirmo que fui capaz de encontrar nesse intelecto labiríntico apenas alguns aspectos dignos de nota; e, longe de terem me levado a partilhar do ceticismo do autor, nenhum obra contribui mais que a sua para me convencer da necessidade e utilidade de boas teorias (Jomini, 1840: p. 205 apud Strachan, 2008: 15-16).

A crítica de Jomini parece carregar um forte elemento pessoal, uma vingança pelas palavras ríspidas de Clausewitz direcionadas a ele no Livro II, capítulo 2, em Da Guerra, ao discutir a teoria das linhas interiores:
Embora este princípio se apoie num terreno sólido - no fato de que o engajamento é o único meio eficaz na guerra - o seu caráter puramente geométrico ainda o torna outro princípio desprovido de equilíbrio, que nunca poderia prevalecer numa situação real.

Só analiticamente estes atentados à teoria podem ser chamados de avanços no campo da verdade. Em síntese, nas regras e nos preceitos que oferecem, são totalmente inúteis.

Eles visam a valores inalteráveis, mas na guerra tudo é incerto e os cálculos têm que ser feitos com quantidades variáveis.

Eles orientam o estudo exclusivamente no sentido das quantidades físicas, enquanto que toda ação militar está entremeada de forças e efeitos psicológicos.

Eles só consideram a ação unilateral, enquanto que a guerra consiste numa contínua interação de opostos.

Qualquer coisa que não possa ser alcançada através da escassa sabedoria destes pontos de vista parciais é considerada como estando além do controle científico: reside na esfera do gênio, que se eleva acima de todas as regras.

Pobre do soldado que tem o dever de rastejar ao longo destes fragmentos de regras, que não são suficientemente boas para o gênio, que o gênio pode ignorar, ou rir delas. Não. O que o gênio faz é a melhor regra, e a teoria não pode fazer mais do que mostrar como e porque deve ser assim.

Pobre da teoria que se choca com a razão! Nenhuma dose de humildade pode atenuar esta contradição. Na realidade, quanto maior for a humildade, mais cedo será ela expulsa do campo da vida real pelo ridículo e pelo desprezo (Clausewitz, 1979: 148-149).

É interessante ressaltar que o autor de Da Guerra criticou a primeira obra de Jomini, publicada em 1803 , Traité de Grande Tactique (Tratado das Grandes Operações), a qual se baseou em três premissas centrais:

- A estratégia é elemento central da guerra;

- Toda estratégia é controlada por princípios científicos inabaláveis;

- Estes axiomas preceituam atacar o inimigo, com o máximo das forças disponíveis, sobre o ponto decisivo, para que a estratégia conduza à vitória.

As diretrizes de Jomini mantiveram-se no decorrer de sua vida intelectual, mas a leitura de Da Guerra parece o ter feito refletir sobre a sua teoria da guerra e, novas concepções apareceram em sua obra posterior Princípios da Arte da Guerra: considerou a importância do fator moral; analisou a incoerência de regras fixas; indicou a necessidade de atribuição 
de limites para o papel da teoria; demonstrou certo ceticismo na utilização de cálculos matemáticos; descrença na guerra como uma "ciência positiva"; a distinção entre o conhecimento e a habilidade militar no campo de batalha real e o reconhecimento da ligação entre política e guerra (Shy, 2001; Bassford, 1993). Jomini, no entanto, não assumiu a influência das concepções clausewitzianas em seu trabalho e escolheu prosseguir com o ataque ao general prussiano:

As obras de Clausewitz foram incontestavelmente úteis, ainda que, muitas vezes, isso se deva menos às ideias do autor do que às ideias opostas que faz nascer. Teriam sido ainda mais úteis se não fosse o fato do seu estilo pretensioso as tornar, frequentemente, ininteligíveis. Mas se como autor didático levantou mais dúvidas do que desvendou verdades, como historiador crítico foi um imitador pouco escrupuloso. As pessoas que leram a minha Campagne de 1789, publicada dez anos antes da sua, não contestarão o que acabo de afirmar, pois não houve uma só das minhas reflexões que ele não tenha repetido (Jomini, 1840: 230 apud Martelo, 2009: 27).

Pode-se dizer que a teoria da guerra desenvolvida por Clausewitz representa as ideias da escola militar prussiana, desenvolvidas a partir do século XIX para combater as concepções da escola militar francesa em voga desde o século XVIII. Os pensadores militares franceses estabeleceram sistemas baseados em fórmulas geométricas para enfrentar as suas guerras, buscando encontrar a receita infalível para a vitória. Os teóricos militares prussianos não aceitavam tal premissa e inseriram em suas teorias estratégicas a importância dos aspectos psicológicos, morais e políticos na guerra, fatores que impediam a previsibilidade e padronização dos conflitos. Entre os franceses destacou-se Jomini e, entre os prussianos, Clausewitz. É relevante destacar que Scharnhorst foi o prenunciador dos novos ideais militares prussianos, mas foi Clausewitz quem disseminou este tipo de pensamento militar estratégico que fascinou o Ocidente após o século XIX.

Em 1810, Clausewitz tornou-se professor da Allgemeine Kriegsschule e tutor militar do príncipe herdeiro da Prússia Friedrich Wilhelm (posteriormente, rei Frederico Guilherme, entre os anos 1840-1858). Em 1812, Clausewitz decidiu abandonar o Exército de seu país em um protesto pela decisão dos governantes prussianos em participar conjuntamente com Napoleão na próxima guerra contra a Rússia ${ }^{3}$. O

\footnotetext{
${ }^{3}$ O serviço em outros exércitos era uma prática comum na época, uma vez obtida autorização do governante.
}

general prussiano decidiu então juntar-se ao Exército do czar russo para combater Napoleão. Antes de deixar Berlim, ainda em 1812, escreveu o manuscrito militar Os princípios mais importantes da arte da guerra para completar o meu curso de instrução para sua Alteza Real o Príncipe Herdeiro, mais tarde intitulado Princípios da Guerra ou Instrução para o Príncipe Herdeiro. Esse pequeno livro versou sobre os mais relevantes princípios para se conduzir as guerras (Bassford, 1994; Strachan, 2008), no entanto, traz somente as primeiras reflexões do prussiano sobre as experiências militares vividas, baseando-se quase inteiramente na experiência de Frederico, o Grande, e nas guerras da França revolucionária e Napoleão.

Outros dois escritos de Clausewitz são focados nas experiências com as campanhas napoleônicas das quais havia participado: A Campanha de 1812 na Rússia (iniciado em 1814 e concluído em 1824) e A Campanha de 1815 na França (finalizado em 1827). Princípios e os dois últimos trabalhos históricos supracitados são passos intermediários no progresso das ideias de Clausewitz, trazem elementos importantes para a maturidade de suas teorias, contudo não possuem a mesma sofisticação de Da Guerra (Bassford, 1994). O livro Princípios tem sido muito popular entre os militares, pois versa, em grande parte, sobre temas táticos, aqueles que tratam do emprego das forças armadas em batalha. O problema da apropriação desse livro é o seu tratamento como um resumo da teoria madura de Clausewitz, o que não é, sendo apenas um " $[. .$.$] precursor bastante primitivo$ para sua obra posterior Da Guerra [...]", como propõe Bassford (1994: 10).

Em 1819, Clausewitz começou a redigir sua mais importante obra, Vom Kriege (Da Guerra), livro que eternizaria o autor como notável teórico da guerra e estrategista militar. Após oito anos de intenso trabalho, a obra contava com seis partes das oito planejadas por Clausewitz, além do rascunho dos Livros VII e VIII. Em 1827, Clausewitz considerou revisar os textos, pois acreditava que não estava suficientemente clara a noção de dois elementos centrais de sua teoria: a natureza política da guerra e os dois principais tipos de guerra (Paret, 2001). Em uma nota datada de 1827, Clausewitz relatou o seu anseio em revisar a obra que iniciara alguns anos atrás:

[...] A guerra pode ser de dois tipos, no sentido que, ou o objetivo é destruir o inimigo - para deixá-lo politicamente desamparado e impotente em termos militares, forçando-o a assinar qualquer tipo de paz que nos convenha; ou meramente para ocupar alguns de seus distritos na fronteira, de modo a se poder anexá-los ou utilizá-los como barganha nas negociações de paz. As transições de um tipo 
para outro ocorrerão periodicamente em meu tratamento; mas o fato de os objetivos dos dois tipos serem bastante diferentes deve estar claro a todo o momento, e o seus pontos irreconciliáveis frisados. Essa distinção entre os dois tipos de guerra é um fato real. Contudo, não menos prática é a importância de outro ponto que deve ser deixado absolutamente transparente, o que diz que a guerra é a continuação da política por outros meios. Se isso estiver firmemente gravado em nossas mentes, durante todo o tempo, muito facilitará o estudo do assunto, e o conjunto ficará mais fácil de analisar (Clausewitz, 1979: 65).

Em novembro de 1831, Clausewitz faleceu de cólera aos 51 anos de idade. Portanto, Da Guerra é um livro inacabado, que veio a ser publicado em 1832 por iniciativa da esposa de Clausewitz, Marie von Brühl (1779-1836), que pode ser considerada sua primeira leitora. A teoria de Clausewitz em sua forma final foi alcançada somente nos anos finais de sua vida, entre 1827 e 1830, quando o prussiano definitivamente compreendeu o papel da política nas guerras. Clausewitz não conseguiu, no entanto, revisar todo seu livro após chegar a sua ideia final, somente o capítulo 1 do Livro I (e talvez o Livro VIII) pode ser considerado definitivo quanto ao pensamento conclusivo do prussiano (Aron, 1986) ${ }^{4}$.

Muitos leitores de Clausewitz decidiram adotar Da Guerra como um manual de instruções para as operações de guerra e desvirtuaram o objetivo de seu autor. A proposta prática de Clausewitz não foi fornecer um guia de ação para militares em campo, mas sim oferecer um guia de estudos sobre a guerra, apresentando aos interessados um esquema conceitual para entender a guerra nas várias formas em que se manifesta através da história (Bassford, 1994). Em Da Guerra, Clausewitz convictamente defendeu a impossibilidade de "princípios eternos da guerra", visto que a guerra variaria em suas formas, dependendo das transformações naturais da política e da sociedade na qual ela é travada (Bassford, 1993). Clausewitz não viu a guerra sobre o prisma da imutabilidade, e sim da incerteza, que são os verdadeiros elementos da guerra (Strachan, 2008). A guerra, para Clausewitz, seria um fenômeno humano e social incerto, que não poderia e muito menos deveria ser tratada como uma ciência exata, por isso afastou-se do pensamento estratégico vigente em seu tempo que via a guerra a partir de um prisma mecânico, calculável matematicamente.

Em linhas gerais, as principais concepções contidas em Da Guerra e que consagraram Clausewitz como

${ }^{4}$ No Livro VIII não há ainda indício da definição trinitária da guerra. um dos principais pensadores da guerra, política e estratégia são ${ }^{5}$ :

- "A guerra é a continuação da política de Estado por outros meios", conceito que expressa o imperativo da subordinação militar à política;

- Dupla natureza da guerra: distinção entre guerra absoluta e guerra real, ressaltando-se o caráter irreal e ideal do primeiro tipo de guerra e, a inserção da política como elemento central para a compreensão das guerras reais;

- A inserção das forças morais e valores subjetivos como essenciais na condução das guerras;

- Relativismo histórico, indicando que cada período tem o seu próprio tipo de guerra e as circunstâncias restritivas adequadas à conjuntura histórica;

- Trindade da guerra, conceito formado por três tendências predominantes, que agem como forças no interior da guerra e que estão presentes em todas as guerras já empreendidas: a violência que funciona como o impulso para a luta contra o inimigo; o jogo do acaso e da probabilidade que permeia os combates e faz da guerra um fenômeno imprevisível e incalculável e, o elemento de subordinação, afinal a guerra é apenas um mero instrumento da política, através do Estado, para alcançar determinados propósitos;

- Relação dinâmica entre defesa e ataque, destacando-se a primazia da defesa que repele o ataque ou resiste a ele, permitindo a conservação de uma situação ou posição.

Após apresentar os principais conceitos de Clausewitz e o contexto no qual formulou suas ideias, partiremos para a recepção de suas ideias entre leitores civis e militares.

\section{I e II Guerras Mundiais: Clausewitz, 0 Apóstolo da Guerra Total}

$\mathrm{O}$ amplo reconhecimento de Clausewitz veio após dois momentos históricos consecutivos - vitória

\footnotetext{
${ }^{5}$ Huntington nos fornece uma reflexão essencial sobre a importância de Clausewitz para o estudo das guerras: "[...] Sua grande e significativa contribuição ocorre num nível mais alto de análise e diz respeito à natureza inerente da guerra e das relações da guerra com outras formas da atividade humana. É óbvio que Clausewitz não se isolou das correntes intelectuais a seu redor. Outros escritores militares também estavam trabalhando na mesma direção e muitos deles anteciparam pontos de vista encontrados em Da Guerra. Mas expressaram-se através de generalidades, mostrando aspectos meramente incidentais das mudanças que estavam ocorrendo na natureza da guerra. No trabalho de pesquisar e expressar a essência dessas transformações, Clausewitz esteve sozinho. Por essa razão, ocupa, merecidamente, no pensamento militar um lugar comparável ao de Marx na história da teoria socialista: muitos dos escritos que apareceram antes dele foram preliminares, fragmentários e subsequentemente incorporados à sua obra; os que apareceram depois foram exegéticos e interpretativos da importância do mestre." (Huntington, 1996: 74).
} 
da Prússia sobre a Áustria em 1866 e, o triunfo da Prússia sobre a França nos anos de 1870 e 1871 - e que culminariam em um evento maior, a unificação da Alemanha (Strachan, 2008). Após tais sucessos o Exército alemão passou a ser visto como um exemplo a ser seguido pela Europa, e Carl von Clausewitz foi considerado o mentor intelectual desse exército bem sucedido. Pela primeira vez, Da Guerra foi traduzido para o inglês, em 1873, pelo coronel James John Graham (1808-1883). A partir desse momento houve maior acesso à teoria de Clausewitz nos países de língua inglesa, principalmente no meio militar (Bassford, 1994; Strachan, 2008).

O oficial responsável pelas vitórias da Prússia sobre a Áustria e a França, Helmuth von Moltke (1800-1891), elencava Da Guerra entre os livros que o haviam inspirado, mas nunca se comprovou que Moltke tivesse tido algum tipo de convivência pessoal com Clausewitz e que de algum modo tivesse seguido suas concepções ${ }^{6}$. Contudo, tornou-se uma máxima a ideia de que aquele tinha sido o instrutor intelectual de Moltke, o responsável por incuti-lo no ideal de aniquilação do inimigo. Moltke é considerado assim um dos principais propagadores de Clausewitz entre os militares alemães (Strachan, 2008). É relevante observar que Moltke enfatizava primordialmente a percepção de destruição total do inimigo, sem considerar outros elementos da teoria clausewitziana.

A Alemanha apostou na capacidade de seus generais para adaptar as doutrinas militares vigentes nas guerras passadas (contra a Áustria e a França) às inovações políticas e bélicas que se alastravam pelo continente europeu e que determinavam um novo tipo de guerra. Os generais alemães defendiam a necessidade de implantação da ideia de guerra total, baseada no princípio da ofensiva e de grandes exércitos modernos que desmantelariam com facilidade o inimigo (Schneider, 1975) ${ }^{7}$. O preconizador de tal modelo de guerra foi o sucessor de Moltke, o marechal de campo Alfred von Schlieffen (1833-1913). Schlieffen foi o responsável por fazer a transição para a nova doutrina do Exército alemão, baseada em um plano de organização dos estados-maiores e da estruturação militar para a ofensiva. O marechal alemão foi também um leitor assíduo de Clausewitz e baseou seu plano de guerra em diversos conceitos clausewitzianos. Contudo, o conceito central que

\footnotetext{
${ }^{6}$ Moltke participava da Academia de Guerra na qual Clausewitz era o diretor. No entanto, no ano de 1820, Clausewitz não ministrava aulas na Academia (Howard, 1983; Strachan, 2008).

É relevante destacar que o conceito de guerra total foi criado por Schlieffen e não tem relação com o conceito de guerra absoluta de Clausewitz.
}

Schlieffen foi buscar em Clausewitz era, tal como seu precursor Moltke, o da aniquilação do inimigo ${ }^{8}$.

A destruição do inimigo através do combate parece ter sido a ideia clausewitziana mais apropriada pelos escritores estratégicos alemães no século XIX. Ao que parece muitos citaram Clausewitz não por suas obras, mas através dos escritos de Moltke e pelas ações de Schlieffen, que disseminaram com vigor a importância do aniquilamento do adversário. O fascínio dos alemães pela "aniquilação clausewitziana" parece ser produto da primazia que a ofensiva adquiriu na doutrina militar desde meados do século XVIII e que atingiu o apogeu entre os séculos XIX e XX. Não havia espaço para a concepção clausewitziana da defensiva ou para os dois tipos de guerra. Assim sendo, a leitura utilitarista de Moltke e Schlieffen era a "ideal" para a conjuntura histórica vivida pelos militares alemães no século XIX.

A França, após sua derrota para a Prússia, passou a ter maior interesse pelo estudo de Clausewitz e sua obra Da Guerra. Em 1885, Lucien Cardot (18381920) promoveu um curso sobre o pensamento de Clausewitz no Colégio Militar, e dois anos depois, o tenente-coronel Valtry fez uma nova tradução de Da Guerra, destacando que essa nova tradução só abarcava os Livros III a VI ${ }^{9}$. Ferdinand Foch (1851-1929), o oficial que em 1918 iria conduzir as forças aliadas francesas, britânicas e norte-americanas no front ocidental da Primeira Guerra Mundial, foi ouvinte de Cardot e Valtry no Colégio Militar e, sua leitura de Da Guerra ajudou a marcar a imagem de Clausewitz para o início do século XX: apóstolo da guerra total, idealizador de uma filosofia amoral da guerra ofensiva que conjeturou ou determinou os desastres da Primeira Guerra Mundial. Evidencia-se que a visão de Foch e de outros leitores franceses de Clausewitz não se afastou das ideias propagadas também pelos alemães.

A principal lição do general prussiano para as guerras modernas, na visão de Foch, era o aniquilamento do exército rival, através da batalha e da força. Em sua visão, era imprescindível que o conceito de guerra absoluta fosse retomado (Schneider, 1975; Strachan, 2008). Percebe-se ainda que Foch, assim como Moltke, enfatizou a importância da destruição

\footnotetext{
${ }^{8}$ Para ressaltar a importância de Clausewitz para Schlieffen podemos citar que a edição alemã de Da Guerra de 1905 (umas das quatro edições publicadas em alemão antes da Primeira Guerra Mundial) trouxe um prefácio escrito por ele, então chefe de Estado-Maior alemão. (Strachan, 2008).

9 Da Guerra foi dividido em oito livros: (1) Sobre a natureza da guerra; (2) Sobre a teoria da guerra; (3) sobre a estratégia em geral; (4) Engajamento; (5) Forças militares; (6) Defesa; (7) O ataque e, (8) Planos de guerra.
} 
do adversário. Foch e Moltke, como inúmeros outros leitores da teoria clausewitziana, parecem não ter considerado a evolução do pensamento de Clausewitz quanto ao caráter irreal da guerra absoluta. Como voltar ao conceito da guerra absoluta se esta na verdade é uma abstração filosófica, uma consideração semelhante a um tipo ideal weberiano? A guerra absoluta é como uma forma pura de guerra, em que a violência atua em sua forma mais extrema e que não possui restrições por "forças inteligentes" (Bassford, 1994). É a guerra de derrubada do inimigo por meio da destruição de seus meios para resistir. Mas, em seus últimos três anos de vida (1827-1830), Clausewitz alcançou completamente a distinção entre o conceito e a realidade, o que lhe permitiu passar da definição inicial da guerra à definição trinitária, a concepção final de sua maturidade intelectual (Aron, 1986), que discutiremos mais detalhadamente nas páginas seguintes deste artigo.

A partir das ideias expressas por Moltke e Foch (principalmente as de Foch) vieram as críticas ao prussiano, e a mais veemente delas partiu de Basil Henry Liddell Hart (1895-1970), que culpou Carl von Clausewitz pelo massacre da Primeira Guerra Mundial, declarando:

O princípio da força de Clausewitz, sem limite e sem cálculo de custo, convém unicamente a uma turba enlouquecida pelo ódio. É a negação da arte de governar - e da estratégia inteligente que procura servir aos fins da política. (Hart, 1933: p. 69 apud Strachan, 2008: 22).

A mesma crítica de Hart foi proferida por John Frederick Charles Fuller (1878-1966), este, no entanto, posteriormente (principalmente após 1945) reconsiderou a "culpa" de Clausewitz na Primeira Grande Guerra.

Liddell Hart que havia participado ativamente no front da Primeira Guerra Mundial foi o principal responsável pela disseminação de Clausewitz como "gênio do mal do pensamento militar", o "apóstolo da guerra total", e como um defensor incansável da massa e da ofensiva (Bassford, 1994). Liddell Hart defendeu veementemente que Clausewitz e seus discípulos foram os culpados pelos massacres ocorridos entre os anos de 1914 a 1918. Na visão de Liddell Hart, Clausewitz era um autor obscuro, de abordagem metafísica, de generalizações abstratas e de difícil entendimento (Bassford, 1994; Strachan, 2008). A imagem que Liddell Hart promoveu de Clausewitz foi uma das mais influentes no período entre guerras. Suas palavras hostis e, muitas vezes errôneas, ecoaram profundamente nas ideias dos militares britânicos de sua geração (Bassford, 1994) ${ }^{10}$. Certamente Liddell Hart não considerou a premissa de Clausewitz de que as guerras são determinadas pela estrutura social e política de cada época (Howard, 1983).

Fuller, que igualmente participou das batalhas da Primeira Guerra Mundial, ao contrário de Hart, não teve uma visão estática de Clausewitz e passou por uma "evolução" sobre a compreensão da teoria clausewitziana. Nas décadas de 1920 e 1930 Fuller utilizou poucas ideias de Clausewitz, ignorando, por exemplo, a percepção central do autor: a relação entre política e guerra. Em 1926, assumiu uma postura anticlausewitziana, afirmando que Da Guerra não passava de um pouco mais de que uma massa de notas envolvidas em uma nuvem de fumaça (Bassford, 1994). No ano de 1932, endureceu sua reprovação ao general prussiano, alegando que sua teoria não tinha mais utilidade e que seus escritos eram obsoletos. A partir de 1936, Fuller começou a mudar seu posicionamento quanto a Clausewitz, suas amargas palavras contra o prussiano foram cedendo espaço a um discurso mais positivo. Após 1945, em um lento processo de reestruturação de seu pensamento, Fuller apresentou outra visão sobre o general prussiano: fora Clausewitz o responsável pela vasta expansão da guerra limitada - aquela permeada pela racionalidade da política - para o século XX (Bassford, 1994).

Em seu livro de 1961, A Conduta da Guerra, Fuller dedicou um capítulo inteiro à discussão de algumas ideias de Clausewitz. O capítulo IV intitulado "As teorias de Clausewitz" tratou das seguintes concepções clausewitzianas: a guerra como instrumento da política; a grande estratégia e o centro de gravidade; os princípios da guerra; a defensiva como a forma de guerra mais forte; a batalha decisiva; a guerra do povo e o desprezo de Clausewitz pela guerra napoleônica. As temáticas apresentadas para o estudo de Clausewitz constituem aquelas, que na visão de Fuller, não são obsoletas e continuam exercendo influência nas guerras subsequentes à época do prussiano, dentre estas se destaca a primeira: "[...] sua análise penetrante das relações da guerra com a política jamais foi superada e é mesmo mais importante hoje do que quando foi apresentada pela primeira vez [...]" (Fuller, 2002: 63).

\footnotetext{
${ }^{10}$ Para citar um exemplo da influência de Liddell Hart, temos os escritos datados de 1946 do historiador do Corpo de Fuzileiros Navais dos Estados Unidos da América, Lynn Montross (1895-1961): "A longo prazo, um teórico militar deve ser julgado não só por seus escritos, mas também pela interpretação deles sobre o futuro nos campos de batalha... Se Clausewitz é considerado o pai da época mais sangrenta e do desperdício de guerra nos tempos modernos, é porque mentes menores aceitaram sua filosofia ao invés de suas táticas. Suas frases brilhantes, em vez de suas modificações sóbrias." (Montross, 1946: p. 87 apud Bassford, 1994: 75, tradução minha).
} 
Após a Primeira Guerra Mundial, os militares do Exército alemão passaram a avaliar as causas de sua derrota e chegaram à conclusão de que o seu fracasso estava em ter desconsiderado as concepções clausewitzianas presentes no conflito. A partir de 1918 até a Segunda Guerra Mundial ver-se-ia uma Alemanha focada em "[...] adaptar constantemente o ensino dos grandes clássicos do século XIX às circunstâncias particulares da guerra do momento [...]" (Schneider, 1975: 110). Manteve-se o conceito da ofensiva como central nas guerras que iriam enfrentar no futuro, mas as novas tecnologias bélicas - aviões, carros e novas armas - foram igualmente fundamentais na elaboração dos novos planos de guerra dos alemães. Já na França criou-se uma ojeriza da população quanto à guerra, devido aos altos custos advindos da Grande Guerra, mesmo com a ameaça de Hitler a reação francesa baseou-se muito mais em uma atitude defensiva (Schneider, 1975). O Exército francês caiu em certo imobilismo com a recusa da sociedade em custear as despesas para renovar as suas Forças Armadas, fato que ocasionou sérios problemas para o país na Segunda Guerra Mundial.

A criação de novas tecnologias bélicas, sobretudo o advento das armas nucleares, provocou uma discussão ainda mais forte sobre a validade da teoria clausewitziana. Ao fim da Segunda Guerra Mundial surgiram diversos intelectuais interessados em debater como Clausewitz poderia ajustar-se aos novos tempos, as novas guerras e as novas estratégias. Com o início da Guerra Fria (1945-1989) Clausewitz angariou críticos fervorosos e defensores entusiasmados, principalmente, acerca da validade da trindade da guerra. Veremos, a seguir, algumas abordagens sobre a trindade clausewitziana no período da Guerra Fria.

\section{Guerra Fria: Clausewitz, o Teórico da Trindade da Guerra}

O ano de 1976 marcou um novo olhar acadêmico sobre Clausewitz com a publicação do livro de Raymond Aron, Pensar a guerra, Clausewitz (dois volumes), uma das mais profundas e completas obras sobre o general prussiano. Aron desenvolveu uma tese chave para o entendimento da teoria clausewitziana: a não linearidade de seu pensamento. $\mathrm{O}$ teórico francês enfatizou que somente nos últimos três anos de sua vida, entre 1827 a 1830, é que Clausewitz chegou ao estado final de seu pensamento, quando finalmente compreendeu o caráter irreal da guerra absoluta e elaborou a concepção da trindade da guerra (Aron, 1986).

A definição trinitária é a evolução final da teoria clausewitziana, quando Clausewitz compreendeu a irrealidade da guerra de derrubada e destruição do inimigo e, alcançou a compreensão da guerra real, que possui fatores moderadores que impedem que as guerras atinjam a tendência aos extremos (Aron, 1986). Raymond Aron observou que Clausewitz passou por três conceituações de guerra: definição monista, dualista e trinitária. A primeira é encontrada em suas primeiras obras, tal como Princípios da Guerra, e pressupõe que a guerra é a derrubada política e a destruição militar. A definição dualista baseia-se na compreensão resultante de seus estudos históricos de que as guerras são muito diferentes em sua intensidade e em seu desenvolvimento para que o princípio do aniquilamento possa explicá-las. Clausewitz compreendeu que uma teoria da guerra deveria abranger todos os tipos de guerra, até mesmo aquelas que não correspondiam ao que parecia ser a essência da guerra, que tinham "[...] objetivos militarmente limitados, sem a intenção de destruir ou abater o Estado inimigo [...]" (Aron, 1986: 136). A definição trinitária sucedeu a dualista, mas não a suprimiu, a trindade de Clausewitz se opõe à definição monista, mas não à dualista, "[...] que se situa no nível da experiência histórica [...]" (Aron, 1986: 137). A trindade da guerra representa um progresso na elaboração conceitual de Clausewitz.

Em Da Guerra, lembra-nos Aron, Clausewitz assimilou concretamente o fato de que a guerra não é uma coisa autônoma, mas apenas um fragmento do conjunto político (Aron, 1986). Isso não quer dizer que considerações sobre a relação entre a política e a guerra não tenham aparecido nas obras anteriores do prussiano, contudo, é no Vom Kriege, particularmente no capítulo 1 do Livro I, que a política apareceu como decisiva na conduta da guerra. A concepção da guerra como um meio da política ainda proporcionou a Clausewitz a compreensão de que o fim da guerra não seria a vitória, mas a paz (Aron, 1986). Tal raciocínio poderia constituir uma resposta aos leitores que alcunharam Clausewitz de teórico inescrupuloso da guerra total.

Ainda em 1976, Da Guerra ganhou uma nova tradução para o inglês, feita por dois importantes historiadores, Michael Howard (1922-) e Peter Paret (1924-) pela Princeton University Press. Esta tradução marcou um novo olhar sobre Clausewitz. No contexto do pós-Guerra do Vietnã (1955-1975), a missão da tradução de Howard e Paret era a de atrair os soldados para a leitura de On War, talvez por isso Howard tenha escrito que Clausewitz era

[...] acima de tudo um soldado profissional escrevendo para seus colegas de profissão, não um acadêmico proferindo uma palestra numa faculdade de Ciência Política. (Howard, 1983: 1, tradução minha). 
A tradução foi eficaz em conquistar novos leitores, no início da década de 1990 o livro, com esta nova tradução, já havia vendido em torno de quarenta mil cópias (Bassford, 1994) ${ }^{11}$. Algumas críticas foram lançadas a essa tradução, sobretudo, por Paret e Howard terem interpretado Clausewitz segundo as aspirações de sua época.

Em tal ponto é interessante observar uma diferença crucial entre o estudo clausewitziano produzido por Peter e Howard (1976) daquele lançado por Raymond Aron, também em 1976: a linearidade ou não linearidade do pensamento de Clausewitz. Como visto anteriormente, Aron defendeu a ideia de que Clausewitz só alcançou a maturidade de seu pensamento em seus três anos finais de vida (1827-1830), quando alicerçou a concepção da trindade da guerra. Howard e Paret, no entanto, discordam de tal visão e alegam que Clausewitz já abarcava em seus escritos iniciais os principais conceitos encontrados em Da Guerra. Ou seja, para estes dois autores o pensamento de Clausewitz é linear e fluído, não apresentando nenhum momento de ruptura e auge, como sugeriu Aron.

Um dos primeiros militares a corresponder aos anseios de Howard e Paret - empenhando-se na leitura de Da Guerra no período da Guerra Fria - foi o então coronel Colin Powell (1937-), que escreveu sobre a obra: "[...] é um raio de luz vindo do passado e que ainda ilumina as perplexidades militares do presente [...]" (Powell e Persico, 1995: 207 apud Strachan, 2008: 8). Powell procurou em Da Guerra o motivo para o fracasso dos Estados Unidos da América em sua guerra contra o Vietnã, e para ele a resposta estava na trindade da guerra, que em sua visão se resumia nos elementos: soldado, forças armadas e povo. Para o general americano, o país que não apresentasse a consonância desses três componentes não encontraria sucesso na guerra. Outro oficial norte-americano de alta patente, o coronel Harry G. Summers Jr. (19321999), usou também a "trindade clausewitziana" para tentar explicar o fracasso dos Estados Unidos no Vietnã. Em um estudo preparado para US Army War College intitulado "On Strategy: A Critical Analysis of the Vietnam War”, publicado em 1982, Summers utilizou-se amplamente da teoria clausewitziana para enfatizar que os Estados Unidos da América falharam

\footnotetext{
${ }^{11}$ Strachan criticou a tradução de Paret e Howard por interpretar as palavras de Clausewitz para o contexto vivido por eles, em sua opinião, essa alternativa lhes proporcionou clareza sobre Da Guerra, mas "[...] ocasionalmente gerou imprecisão e mesmo erros de interpretação.” (Strachan, 2008: 131). Bassford também fez críticas à tradução de Howard e Paret e indicou como a melhor versão de Vom Kriege para a língua inglesa a tradução realizada por Jolles, no ano de 1943
}

em tratar da questão de como utilizar meios militares para alcançar um fim político no Vietnã (Strachan, 2008). O livro de Summers teve intensa repercussão entre os militares norte-americanos e até 1983 já havia sido reimpresso três vezes.

O coronel Summers continuou seu estudo sobre Clausewitz e a relação com a Guerra do Vietnã (1955-1975) e em 1983 publicou no periódico militar, Naval War College Review, o texto "Clausewitz and Strategy Today". Seguindo a mesma linha de seu texto anterior, Summers focou Clausewitz como um autor adequado e atual para se entender os problemas estratégicos que os Estados Unidos enfrentaram no conflito contra o Vietnã. Mesmo passados mais de cento e cinquenta anos da publicação do clássico livro Da Guerra, não havia outro livro que trouxesse tantos ensinamentos para aquele momento em que erros sobre as concepções da guerra se tornavam tão evidentes, tal como no século de Clausewitz (Summers, 1983). A lição de Clausewitz para os Estados Unidos a partir da experiência no Vietnã, segundo Summers (1983), é a percepção de que as guerras não podem ser ancoradas unicamente no campo militar, elas devem ser pautadas na trindade clausewitziana, que a seu ver, resumir-se-iam em três subsídios: soldado, forças armadas e povo. São estes os elementos que tem a corresponsabilidade pelo sucesso ou fracasso na condução de qualquer guerra moderna (Summers, 1983).

Clausewitz exerceu uma impressionante fascinação entre os norte-americanos no pós-Vietnã. Sua teoria tornou-se tão popular e citada entre os militares dos Estados Unidos que seria impraticável discutir aqui as inúmeras menções ao prussiano nesse período. Através das palavras de Summers (1983) e Powell e Persico (1995), observa-se a influência que os conceitos clausewitzianos tiveram para explicar os fracassos na Guerra do Vietnã. Destacou-se a trindade - povo, exército e governo - como enunciada por Colin Powell e Harry Summers Jr. A trindade é dada por três tendências dominantes que agem no interior de qualquer guerra: (1) violência primordial, ódio e inimizade; (2) jogo do acaso e da probabilidade; (3) guerra subordinada à política racional. Cada uma dessas três categorias afeta, principalmente, um determinado conjunto de atores: (1) povo; (2) exército; (3) governo ${ }^{12}$. Nota-se que a versão da trindade lançada por alguns militares norte-americanos é distinta da concepção central de Clausewitz: deriva

\footnotetext{
${ }^{12}$ Ressalta-se que cada uma das três tendências que formam a trindade clausewitziana afetam de forma variável todos os grupos de atores humanos, Clausewitz tentou demonstrar como cada tendência age como força principal em cada conjunto humano, mas não delimitou a interação das tendências entre os grupos (Bassford; Villacres, 1995).
} 
da ilustração do conceito e não do próprio conceito (Bassford e Villacres, 1995). Tal interpretação não permite a investigação de todas as alusões relevantes da ideia trinitária, pois, baseia-se em somente uma das formas possíveis das tendências discutidas por Clausewitz. Por isso, enfatizamos que a trindade deve ser assumida como pensada pelo teórico prussiano: forças dominantes (violência, o jogo do acaso e da probabilidade e seu elemento de subordinação) que atuam sobre todos os elementos (povo, exército e governo).

Enquanto entre os militares, no período pós-guerra Fria, Clausewitz parece manter-se atual e expressivo, no meio acadêmico sua permanência é controversa e polêmica. Para alguns autores, no novo cenário de guerras tecnológicas, a natureza da guerra mudou e dessa forma Da Guerra perdeu sua relevância. De outro lado, há pensadores que defendem a importância e a contemporaneidade de Clausewitz e de sua obra. Sigamos esse fervoroso debate no próximo tópico.

\section{Pós-Guerra Fria: Clausewitz, Obsoleto ou Atual?}

Após a Guerra do Iraque (1990-1991), em inícios da década de 1990, alguns autores especializados em assuntos militares passaram a debater o surgimento de um novo tipo de guerra, que não podem mais ser designadas "clausewitzianas": a guerra passa por uma intensa transformação, na qual muda significativamente a sua configuração de associação com o Estado. Dois representantes centrais de tal pensamento são: Mary Kaldor com a obra New and Old Wars (1999) e Martin van Creveld (1991), The Transformation of War. A ideia fundamental de Kaldor (1999) e Creveld (1991) é: a teoria de Clausewitz foi superada, pelo menos em dois pontos: (1) a guerra não é mais um fenômeno da política interestatal e, cada vez mais há a possibilidade de que aconteça sem o controle do Estado; (2) as guerras do século XXI não mais conjecturam, em sua dinâmica interna, a "trindade clausewitziana", seja pela inserção de novas tecnologias bélicas, ou, por não serem mais empreendidas por um povo, um exército e um governo (Strachan, 2008; Silva, 2003).

Mary Kaldor distinguiu as "guerras antigas" aquelas estudadas por Clausewitz e que se baseavam no princípio da guerra com um ato de força destinado a realizar os objetivos da política - das "novas guerras", cujos interesses (não exatamente políticos) exigem a continuidade do conflito e não sua resolução: são guerras que buscam outras guerras e não a paz. As "novas guerras" acontecem através da erosão do Estado, o que torna a teoria clausewitziana obsoleta e inadequada para a compreensão das guerras mais atuais (Kaldor, 1999). Creveld (1991), por sua vez, se opôs ao que ele designou de "universo clausewitziano": as guerras do pós-1945 não se centram mais nas guerras feitas por Estados (ou governos) e a visão clausewitziana da guerra como uma trindade (povo, exército e governo) é simplesmente inaplicável para o mundo emergente da era da Guerra Fria. Sendo assim, Clausewitz estava definitivamente superado (Creveld, 1991). Observamos novamente a utilização da definição trinitária de modo não correspondente à formulada por Clausewitz, no entanto, desta vez empregada para decretar a obsolescência do prussiano.

Defendendo a atualidade do pensamento de Clausewitz temos: Christopher Bassford, Clausewitz in English: The Reception of Clausewitz in Britain and American (1994) e Hew Strachan, Sobre a Guerra de Clausewitz [uma biografia] (2008). O argumento central, de Bassford (1994) e Strachan (2008), é que Clausewitz foi lido, muitas vezes, de forma seletiva, o que impediu que vários leitores alcançassem a compreensão exata da teoria clausewitziana. Cada geração se predispôs a ler Clausewitz segundo as apreensões de seu contexto, desconsiderando a conjuntura histórica na qual viveu o general prussiano, o que certamente implica em uma leitura enviesada de Clausewitz (Strachan, 2008). Outros ainda leram Clausewitz a partir de outros escritores, sem contato algum com as obras do próprio autor, o que leva, muitas vezes, a confusão e "mistura" das ideias de terceiros com a de Clausewitz (Bassford, 1994). A advertência de Bassford (1994) e Strachan (2008) é simples: temos que retornar a leitura do próprio Clausewitz, inserindo-o em seu próprio contexto histórico e não no nosso.

Aderimos à visão de Christopher Bassford (1994) e Hew Strachan (2008): a teoria de Clausewitz é válida e relevante para a contemporaneidade. A trindade clausewitziana, ao contrário do que argumentaram Kaldor (1999) e Creveld (1991), abre a possibilidade de reflexão sobre as "novas guerras", pois Clausewitz observou que a trindade pode mudar radicalmente de caráter, adaptando-se ao contexto histórico, político e social de cada tempo, visto que a natureza da guerra é determinada por um conjunto de forças sociais e pelo espírito de sua época. Recomenda-se que Clausewitz não seja retirado de sua conjuntura histórica e deslocado para o nosso tempo, a leitura de sua obra principal, Da Guerra, deve sempre ser guiada pelo pensamento de que Clausewitz era um homem de seu tempo e que sua reflexão é notadamente marcada pelas experiências que vivenciou.

Após traçar a trajetória de Clausewitz e a repercussão de sua teoria ao longo do tempo, 
focaremos as leituras e apropriações deste autor no Brasil, logo após o fim da Guerra Fria.

\section{Leituras Brasileiras de Clausewitz: Visões da Trindade da Guerra}

O sistema internacional no período da Guerra Fria construiu-se em torno de duas superpotências que tinham visões militares distintas e modelos de sociedade divergentes. Enquanto os Estados Unidos defendiam uma democracia liberal de mercado, na outra ponta a União Soviética apoiava uma ditadura do proletariado com economia planificada (Alves, 2007). Com o encerramento da Guerra Fria e do sistema bipolar entre os anos de 1989 e 1991 surgiu um novo cenário político-estratégico no mundo, no qual as hipóteses de guerra tradicional afastavam-se e as percepções de segurança no mundo eram reinventadas devido à falta de inimigos claros. O papel das forças armadas foi igualmente repensado no plano internacional, suas funções deveriam adequar-se aos novos tempos e às novas ameaças.

A falta de inimigos no pós-Guerra Fria transformou os conceitos de segurança e defesa em âmbitos internacional e nacional, visto que estas concepções pareciam ultrapassadas aos novos tempos, que produziam outros tipos de conflitos que não os convencionais. A Organização do Tratado do Atlântico Norte (OTAN) reconfigurou o seu conceito estratégico entre os anos de 1990-1991, o que levou à revisão das políticas de segurança dos países aliados à Organização. A estratégia da OTAN antes dos anos 90 poderia ser resumida, basicamente, na possibilidade de um ataque surpresa em grande escala efetivado pela União Soviética e seus aliados. Seria necessário contar com uma pronta defesa composta por grandes contingentes próximos às fronteiras da OTAN com o Pacto de Varsóvia, tal estratégia foi denominada de Estratégia de Resposta Flexível (Strategy of Flexible Response) (Castro Santos, 2004). Uma série de debates promovidos pela OTAN, iniciados em 1990, com a Cúpula de Londres e, posteriormente, em 1991, com a Cúpula de Roma, propuseram a reestruturação dos exércitos e missões, norteadas pelos seguintes princípios: cooperação militar, redução e aprimoramento dos contingentes das forças armadas e redução de armas de destruição em massa (Bertazzo, 2007).

Na nova diretriz estratégica da OTAN, os países latino-americanos deveriam focar-se, especialmente, na redução dos seus contingentes, ou seja, as forças deveriam ser menos numerosas, mais flexíveis, modernas e especializadas. Sem inimigos claros (no campo interno ou externo) o que as forças armadas fariam com esses pequenos contingentes, modernamente equipados e especializados? Quais seriam suas funções já que não havia ameaças e inimigos? A solução para este vazio estratégico seria o redirecionamento do papel dos militares para as "novas ameaças" que afligiam a sociedade: tráfico de drogas, terrorismo, combate à proliferação de armas de destruição em massa, pobreza extrema, crescimento populacional desordenado, desigualdade de renda e a questão ambiental (Castro Santos, 2004). Ou seja, a OTAN sugeriu que as forças armadas quando não empregadas na defesa externa poderiam exercer funções adicionais no plano interno (ações emergenciais de defesa civil, controle do território nacional e missões de paz), além de atuar junto às Forças de Paz das Nações Unidas, quando requeridas.

Nesse quadro, Nelson O' de Almeida, coronel aviador, ex-instrutor da Escola de Comando e Estado-Maior da Aeronáutica (ECEMAR) e membro do Corpo Permanente da ESG, publicou em A Defesa Nacional, em 1989, o artigo "Forças Armadas: Apenas Segurança Externa?". O texto teve o intuito de focalizar o papel das forças armadas em fins dos anos 80 , onde prevaleceram, segundo o autor, as guerras psicológicas e o terrorismo de Estado.

$\mathrm{O}$ significado real da guerra pode ser um valioso elemento no entendimento da história da humanidade, talvez por isso vários estudiosos tenham tentado entender o fenômeno bélico, entre eles, ao ver de Almeida (1989: 26), Clausewitz, de quem ele citava: "A guerra é um ato de força para compelir o inimigo a aceitar a nossa vontade e isto inclui dois elementos: o ato de força e a ação psicológica". Para citar essa conhecida definição de Clausewitz, Almeida (1989) utilizou-se de outro livro do prussiano, Princípios da Guerra (uma edição publicada pela Bibliex em 1956) um pequeno manual de instrução direcionado a um príncipe ao qual Clausewitz lecionava sobre a arte da guerra. Quando escreveu este livro, em 1812, o general prussiano ainda não teria concebido a sua ideia máxima da guerra como um instrumento da política, como anteriormente elucidado neste artigo $^{13}$.

O propósito do coronel brasileiro aqui seria salientar a importância das ações psicológicas nos conflitos modernos. Para tanto, agregou outro conceito central - e da fase madura de Clausewitz, segundo a leitura de Aron (1986) - para comprovar a importância do fator psicológico e moral nas guerras modernas, a trindade da guerra - povo, governo e exército - conceito, que para Almeida (1989) teria sido primariamente pensado por Napoleão e

\footnotetext{
${ }^{13}$ Mas, a definição citada apareceria de novo em Da Guerra, antes de Clausewitz compreender totalmente o papel da política na guerra.
} 
codificado pelo prussiano. $\mathrm{O}$ ataque ao moral do governo e do povo fez-se essencial nos conflitos do século XX, razão pela qual, na visão do articulista, a trindade notável de Clausewitz não deveria ser esquecida. A seu ver a relevância e atualidade da trindade clausewitziana podiam ser evidenciadas em pelo menos dois conflitos da Guerra Fria: Vietnã (1955-1975) e Malvinas (1982). Para ele, tais ataques de vertente psicológica ampliaram-se através dos modernos meios de comunicação, mais efetivamente pela televisão. O terrorismo, alicerçado nas guerras de guerrilha, fez amplo uso deste meio para atingir os seus ideais, ou seja, destruir a trindade do país inimigo, especialmente, afetar a sociedade e seu governante (Almeida, 1989).

Mas, há um limite na leitura de Almeida, pois como já evidenciamos neste artigo, a trindade não é baseada nos elementos: povo, governo e exército. Através da trindade da guerra o prussiano fez a transposição da guerra em dois termos, "[...] a guerra é, pois um ato de violência destinado a forçar o adversário a submeter à nossa vontade" (Clausewitz, 1979: 73) para a guerra em três termos:

Uma surpreendente trindade em que se encontra, primeiro que tudo, a violência original do seu elemento, o ódio e a animosidade, que é preciso considerar como um cego impulso natural, depois, o jogo das probabilidades e do acaso, que fazem dela uma livre atividade da alma e, finalmente, a sua natureza subordinada de instrumento da política por via da qual ela pertence à razão pura (Clausewitz, 1979: 89).

Clausewitz logo depois considerou que cada elemento da trindade parece estar mais relacionado com determinados grupos: "[...] o primeiro destes três aspectos interessa particularmente o povo, o segundo, ao comandante e ao seu exército, e o terceiro releva, sobretudo do governo." (Clausewitz, 1979: 89). Clausewitz notou que todas as guerras sofrem em seu interior a ação de três forças - (1) violência, (2) o acaso e a (3) instrumentalidade - que interagem entre si de forma não linear. Clausewitz observou que nas guerras de seu tempo essas forças manifestaram-se, principalmente, por meio de três atores: (1) povo, mobilizado pela raiva ao inimigo; (2) o chefe militar e seu exército, que devem buscar nas improbabilidades de cada combate, a possibilidade da vitória; (3) o governo, por meio do qual a guerra se transforma em um instrumento da política. Os atores - elementos pelos quais as forças atuam - são próprios de cada sociedade e contexto histórico onde incide a guerra. Porém, as forças da trindade não se alteram e estarão presentes em cada guerra empreendida. A trindade representa o progresso conceitual de Clausewitz, dado pelo entendimento da subordinação do chefe militar ao governo e, da compreensão da guerra como apenas um instrumento da política, como nos explicou Raymond Aron (1986). O coronel Almeida apropriou-se tanto da teoria dualista como da definição trinitária, mas ressalta-se que esta evolução só foi percebida no livro Da Guerra e não consta na obra consultada pelo autor, Princípios da Guerra, o que evidencia uma leitura mais restrita de Clausewitz por parte de Almeida (1989).

Mas, nem todos os autores militares concordavam quanto à atualidade de Clausewitz. Parecendo influenciado pelos livros recentes de Mary Kaldor, New and Old Wars (1999) e Martin Van Creveld (1991), The Transformation of War, dez anos depois do final da Guerra Fria, o tenente-coronel Fernando Velôso Gomes Pedrosa, contrariando a atualidade de Clausewitz nos conflitos atuais, publicou n'A Defesa Nacional o texto "Os desafios da paz, as Forças Armadas e os conflitos do futuro". O artigo abordou os conflitos de legitimidade, caracterizados por não envolver disputas entre Estados e por serem motivados por causas irracionais, ódios raciais ou religiosos, ou por fatores relacionados à sobrevivência dos grupos em choque (Pedrosa, 1999).

Estes conflitos são os substitutos dos conflitos de soberania, aqueles marcados por lutas de apropriação da soberania dos outros Estados, através da conquista da população, do território e de outras riquezas. A diferença central entre os dois tipos de conflito dar-se-ia pelo caráter apolítico das guerras derivadas dos conflitos de legitimidade. De tal forma, o autor afirmou que as ideias de Clausewitz não teriam mais significado nos conflitos do século passado, baseando-se também em uma visão limitada e invertida da trindade clausewitziana, tal como pronunciada por Powell, Summers, Kaldor e Creveld:

A lógica de Clausewitz já não se aplica aos conflitos de legitimidade e à violência do crime, que têm natureza essencialmente apolítica. O filósofo alemão entendia que a guerra seria necessariamente conduzida por uma surpreendente trindade formada pelo governo do Estado, seu povo e seu exército, usando meios limitados e visando a alcançar objetivos limitados (Pedrosa, 1999: 112).

A teoria de Clausewitz não seria mais adequada para analisar as guerras do século XX, devido, principalmente, ao fato dos conflitos não terem conotação política, por não mais envolverem a luta entre Estados (Pedrosa, 1999). Os envolvidos seriam grupos criminosos e milícias privadas, que agiriam além das fronteiras do Estado. Tal hipótese que não fora pensada por Clausewitz, diz Pedrosa, que investigou exclusivamente combates envolvendo atores estatais, 
invalidaria a teoria da guerra clausewitziana. Mas, não há consenso na literatura estratégica quanto a esta afirmação de Pedrosa, alguns autores defendem que Clausewitz pode ser utilizado para entender este tipo de conflito. Ainda descartando a atualidade do prussiano, o tenente-coronel Pedrosa assinalou que a limitação da guerra, com a inserção de seu elemento moderador, a política, não é mais conivente para entender as guerras mais atuais:

Os conflitos de legitimidade parecem também anunciar o retorno às guerras de aniquilamento, contrariando o princípio da moderação descrito por Clausewitz. A guerra entendida como continuação da política é, por natureza, limitada pelo seu objetivo, cujo valor condiciona o esforço a ser despendido (Pedrosa, 1999: 112).

A preocupação central de Pedrosa era a ascensão do crime organizado dentro do Estado, ou seja, sua apreensão maior foi com a guerra interna e o papel das forças armadas para repreender os participantes não estatais destes conflitos. Aqui é interessante destacar que o tenente-coronel Pedrosa não se mostrou favorável à utilização das Forças Armadas brasileiras em um "papel policial", criticando as políticas governamentais que não criaram planos efetivos para a segurança pública e a defesa nacional. No entanto, o autor argumentou que as Forças deveriam estar preparadas para cumprir os desígnios estabelecidos pelos superiores, afinal, estas "[...] têm um compromisso histórico com a Nação, da qual são fiadoras da soberania, da unidade e da integridade." (Pedrosa, 1999: 114).

No início da década de 90 os militares pertencentes ao Exército brasileiro opunham-se a ação dada a eles no plano interno - combater o narcotráfico, o crime organizado e, quando necessário, conter a violência e os distúrbios urbanos -, pois consideravam uma função "policial" que não se ajustava à sua missão constitucional: defender a integridade do território e das fronteiras nacionais e garantir os poderes constituídos contra ameaças externas (Castro Santos, 2004). Essa missão deveria ser designada à Polícia Federal para que não houvesse o risco de corrupção das Forças Armadas, caso constatado em outros países. O combate ao narcotráfico foi uma das temáticas centrais de crítica dos militares nas ditas funções policiais, mas em finais da década de 90 parece ter ocorrido uma mudança de postura destes, motivado pelo papel central que a Polícia Federal assumiu nesta questão a partir de 1995, através do "Acordo de Combate ao Narcotráfico" entre Brasil e Estados Unidos. A entrada de norte-americanos na região Amazônica e a autonomia da Polícia Federal parecem ter mudado o discurso dos militares quanto ao seu envolvimento na luta contra o narcotráfico (Martins Filho, 2000).

Nos anos 90 intensificou-se o discurso sobre o imperativo de proteção da Amazônia através de uma "nova ameaça": a internacionalização. Não que as velhas ameaças não estivessem presentes (problemas nas fronteiras, vazios geográficos, narcotráfico, guerrilhas), mas a internacionalização poderia significar a perda da soberania nacional, pensamento que afligia a mente de alguns militares brasileiros. $\mathrm{O}$ vilão desse cenário era aquele que outrora havia sido pensado como aliado ideal por Golbery do Couto e Silva (1911-1987), os Estados Unidos, que desde o final da Guerra Fria passou a ser visto no, campo estratégico, como o principal risco para a soberania brasileira (Martins Filho, 2003) ${ }^{14}$.

O Exército, dentre as três Forças Armadas brasileiras, parece ter a relação mais íntima com a Amazônia. Os escritos geopolíticos anteriores ao fim da Guerra Fria já apontavam a Amazônia como área estratégica prioritária e, a necessidade de "cuidados" com aquele espaço vital. Os militares pertencentes à Força Terrestre parecem ter incorporado este discurso e adotado com fervor o papel de defensores da Amazônia. A defesa da Amazônia parece então ser a nova função das Forças Armadas brasileiras no cenário pós-Guerra Fria, lugar onde encontram o papel tradicional das Forças - defender o território, as fronteiras nacionais - e ao mesmo tempo "descobrem" novas ameaças que devem ser combatidas - narcotráfico, movimentos guerrilheiros de países vizinhos, invasores estrangeiros, organizações não governamentais ambientalistas ou de proteção a populações indígenas (Martins Filho, 2003). Diante de um panorama de "ameaça clara" à Amazônia, o Exército brasileiro passou a refletir sobre a possibilidade de resistência não convencional em uma eventual interferência das grandes potências na região amazônica. A partir de 1995, os planos de resistência não convencional foram incluídos no Sistema de Planejamento do Exército (SIPLEx). O SIPLEx-4 determinou a Amazônia e a área Guianense como central na concepção estratégica do Exército brasileiro e, para pensar os meios de sua defesa instituiu uma doutrina operacional especial para a região, a Doutrina Gama.

\footnotetext{
${ }^{14}$ Golbery do Couto e Silva também foi um leitor de Clausewitz. As palavras de Golbery sobre Clausewitz estão presentes na obra Planejamento Estratégico, de 1955, na qual foram agregadas algumas conferências do autor na Escola Superior de Guerra (ESG). As menções à Clausewitz em Golbery vêm embasadas em Da Guerra, uma tradução em inglês do ano de 1943, sendo que sua leitura focou as seguintes concepções clausewitzianas: guerra como continuação da política por outros meios e os conceitos de atrito e polaridade.
} 
Tal doutrina apresenta duas perspectivas para o enfrentamento de possíveis invasões na Amazônia: uma baseada no combate convencional, se o adversário possuir um poder militar semelhante ou inferior ao do Brasil, e a outra em um conflito não convencional, se o adversário possuir um poder militar incontestavelmente superior ao do Brasil. No primeiro caso, deve prevalecer a estratégia ofensiva, buscando a rápida decisão do conflito através do emprego de forças regulares. Já no segundo caso, prioriza-se a estratégia de resistência, na qual se evita o choque direto com as forças inimigas, através de ações não convencionais e do emprego de forças regulares e mobilizadas.

Já no ano de 1992 podemos situar o pensamento de um plano estratégico diferenciado para a proteção da região Amazônica. Em artigo exposto no periódico A Defesa Nacional "A estratégia indireta, a guerra irregular e a defesa da Amazônia", o coronel da infantaria Carlos Alberto Pinto Silva apontou a guerra irregular, a estratégia indireta e a estratégia de lassidão como recursos a serem utilizados pelo Brasil para defender a Amazônia que "[...] tem sofrido fortes ameaças que atentam contra a soberania nacional." (Silva, 1992: 85).

A estratégia indireta é empregada quando um país não dispõe de meios militares superiores, utilizando-se então da persuasão (meios jurídicos e diplomáticos) e coerção (meios políticos, econômicos e psicossociais) ao invés da expressão militar. Em nível operacional deveria empregar-se a estratégia de lassidão, aquela que se desenvolve através de um conflito prolongado, que busca obter a decisão pela ação psicológica, desgaste moral e esgotamento material do oponente. Tal estratégia pode ser resumida na expressão "saber durar" (Silva, 1992). Estas estratégias seriam usadas em uma guerra irregular, como forma de condução de uma guerra convencional, com o intento de desgastar o inimigo antes da deflagração das hostilidades, ou como forma de opor $\mathrm{o}$ alcance de posições vantajosas ao adversário (Silva, 1992). Observa-se que as concepções estratégicas indicadas pelo coronel Silva (1992) são recomendadas para cenários em que as Forças Armadas brasileiras estariam à frente de um poder militar incontestavelmente superior.

$\mathrm{Na}$ possibilidade de adoção das estratégias indireta e de lassidão, conduzidas através da guerra irregular, não deveria ocorrer a transformação do exército regular em guerrilheiros, pois somente as forças regulares são capazes de produzir decisões estratégicas, ou seja, a manutenção do exército regular é vital na direção da guerra irregular. Para comprovar a importância desta assertiva o coronel Silva buscou as palavras de Clausewitz:
Se quer evitar perseguir um fantasma, deve-se, pois imaginar que uma guerra irregular esteja sempre combinada com guerra conduzida por um exército permanente, ambas concebidas segundo um plano conjunto único (Silva, 1992: 87).

Quatro soluções seriam possíveis a fim de organizar as unidades de guerra irregular: utilização da população local dos municípios do interior, indígenas e garimpeiros; unidades do Exército temporariamente destacadas para tal propósito; unidades permanentes do Exército, separadas para esta finalidade, ou, a combinação das unidades do Exército com combatentes irregulares recrutados dentre a população. Para o coronel Silva, o povo não deveria medir esforços na defesa de seu território, Clausewitz já dissera:

Se o próprio povo não estiver preparado para, se necessário, tomar parte na defesa do seu país, não poderá a longo prazo ser protegido (Silva, 1992: 86)

Neste artigo, o autor não evidencia a concepção da trindade da guerra, mas cita a importância do Exército e do povo para o enfrentamento de ameaças na Amazônia. Dessa forma, parece-nos que o autor se aproxima da visão invertida da trindade, que considera exército, povo e governo como os elementos essenciais presentes nas guerras. Mas, fica a indagação: por que o autor não menciona a relevância do papel do Estado (governo) na dinâmica das guerras?

Pode-se dizer que o padrão básico do profissionalismo militar surgiu na Prússia, por meio dos ideais reformistas propostos por Gerhard von Scharnhorst, August von Gneisenau e Carl von Grolmann (1777-1843), membros da Comissão Militar Prussiana. A partir de 1808, a Prússia suprimiu a concepção de que riqueza, origens familiares e influência pessoal e política ditariam a indicação e promoção de oficiais, desse momento em diante, educação, conhecimentos profissionais e, bravura seriam os elementos necessários para que os indivíduos alcançassem os altos postos militares do Exército prussiano. As transformações militares da Prússia originaram um novo olhar sobre o fenômeno da guerra: destacou-se a importância de serem analisados os aspectos psicológicos, morais e políticos, fatores que impediam a previsibilidade e padronização dos conflitos. Clausewitz pode ser considerado o primeiro formulador de tal tipo de pensamento, que exaltava o profissionalismo militar e discutia a nova face da guerra. Clausewitz ao instituir a dupla natureza da guerra, lançou a base para um conceito de guerra verdadeiramente profissional, que evidenciou o papel do soldado e do Estado na estrutura 
militar. Ao concluir que a "guerra é a continuação da política de Estado por outros meios", ou ainda, que "a guerra tem uma gramática, mas não tem uma lógica", Clausewitz formulou "o primeiro rationale teórico para a profissão militar", como nos explica Huntington:

[...] o fato da guerra possuir gramática própria requer que aos profissionais militares se permita desenvolver sua especialidade segundo essa gramática, sem interferências estranhas. A qualidade inerente de um corpo militar só pode ser avaliada em termos de padrões militares independentes. Entretanto, os fins em favor dos quais se emprega o corpo militar ficam fora de sua competência para julgar: "o objetivo político da guerra realmente se situa fora da província da guerra" [...] Guerra não tem lógica nem objetivos próprios. Eis porque o soldado terá sempre de subordinar-se ao estadista. É da responsabilidade deste a conduta da guerra, pois "exige uma aguçada percepção da política de Estado em suas relações mais altas (Huntington, 1996: 76).

Ao mesmo tempo em que instituiu o profissionalismo militar para a modernidade, Clausewitz "[...] contribui com a primeira justificativa teórica para o controle civil [...]" (Huntington, 1996: 76). Nos termos de Huntington, aceitar Clausewitz é aceitar o controle civil. Isto historicamente não estava na pauta dos militares. Tal fato pode constituir mais um causa para uma leitura seletiva e rasa acerca da teoria clausewitziana entre os militares brasileiros.

Notamos que os textos até aqui analisados apresentaram limitações quanto ao entendimento do conceito central de Clausewitz, a trindade da guerra. Acreditamos que tal fato pode estar relacionado com a leitura de terceiros, sejam militares ou acadêmicos, sobre Clausewitz e não da própria obra do general prussiano, Da Guerra. As preocupações advindas com a "nova ordem" mundial (mudanças estratégicas, novo papel das Forças Armadas, possibilidade de intervenção estrangeira na Amazônia), decididamente influíram nas leituras e apropriações da teoria clausewitziana no Brasil. Contudo, atores humanos não são simplesmente periodizados, ainda que o contexto do tempo determine a aceitação do escritor a partir de algum aspecto particular, às vezes isso pode não acontecer. Não é sempre possível enquadrar vários pensamentos dentro de uma estrutura rígida determinada por eventos históricos, assim interpretações mais refinadas sobre a teoria clausewitziana apareceram entre os militares brasileiros.

No artigo "Por que Clausewitz é considerado um filósofo da guerra?", publicado em 2006, o tenente-coronel Leonardo Ramalho Rodrigues Alves (2006) procurou identificar as influências filosóficas de Clausewitz, apostando em três autores que devem ter deixado suas marcas teóricas em Da Guerra: Espinosa, Kant e Hobbes ${ }^{15}$. Para o autor, é basilar entender Clausewitz como um filósofo da guerra, pois o fato de aliar teorias da guerra com filosofia é que o tornou único na História Militar. Não obstante, destaca Alves,

[...] observa-se que são poucos os trabalhos nas escolas militares de alto nível que versam sobre Clausewitz, sendo que, ao contrário, são cada vez mais numerosos os estudos e ensaios nos meios acadêmicos civis sobre Da Guerra.

E conclui: "Não importa como, mas precisamos ler mais Clausewitz." (Alves, 2006: 21).

Nessa leitura, a metodologia empregada por Clausewitz é outro fator marcante na universalidade e permanência de Da Guerra, pois a junção entre dedução (atributo metodológico de historiadores) e filosofia experimental, baseada na prática militar de Clausewitz, significou um avanço em relação aos livros sobre a arte da guerra publicados até então, a exemplo das obras de Bulow, Berenhorst (1733-1814) e Jomini que apostavam em uma teoria mecanicista da guerra. O que Clausewitz buscou em Da Guerra foi entender a realidade e a essência da guerra, descartando os modelos teóricos baseados em esquemas matemáticos (Alves, 2006).

$\mathrm{Na}$ visão deste autor, três correntes filosóficas foram fortes ao tempo do general prussiano: idealismo, racionalismo e empirismo. O idealismo, datado do século XVII, preocupou-se com as reflexões sobre o sujeito e teve como seu principal expoente o filósofo Immanuel Kant (1724-1804). $\mathrm{O}$ empirismo focalizou a função da experiência no método do conhecimento, teve figuras centrais: Roger Bacon (1214-1294), John Locke (1632-1704) e David Hume (1711-1776). O racionalismo acreditou na razão como a única forma de compreensão e o preceito específico da razão, destacaram-se entre os racionalistas: Descartes (1596-1650), Bento de Espinosa (1632-1677) e Gottfried Wilhelm Leibniz (1646-1716). Na perspectiva de Alves (2006), não é possível que Clausewitz tenha sofrido influência da corrente empirista. Por isso, ele se empenhou em explicitar os prováveis influxos do racionalismo e idealismo em Da Guerra, através de representantes de ambas as escolas filosóficas: Espinosa e Kant. O

\footnotetext{
${ }^{15}$ Neste artigo não há discussão acerca do conceito da trindade da guerra, no entanto, julgamos pertinente demonstrar aos leitores que há leituras mais elaboradas, refinadas, quanto à teoria de Clausewitz entre os militares brasileiros.
} 
monismo de Espinosa pode ter inspirado Clausewitz na construção de seu pensamento mais famoso: a subordinação da guerra à política.

É clara, em toda a extensão de Da Guerra, a unidade de guerra e política, pois, para o prussiano, 'a guerra é apenas uma parte do intercurso político, não vindo a constituir em absoluto uma atividade independente', arrematando logo a seguir que, sem a subordinação à política, 'a guerra é uma insensatez sem nenhuma finalidade.' (Alves, 2006: 18).

A modalidade ou modo, em Espinosa, tem a acepção de "[...] acidente, particularidade e de individualidade, qualquer forma ou formato que a realidade assuma transitoriamente." (Alves, 2006: 18). E qual a analogia com a teoria de Clausewitz? Para o tenente-coronel, a conceituação do prussiano sobre a "dupla" defesa-ataque tem um toque da ideia de modalidade de Espinosa devido ao caráter acidental, particular ou individualizado.

As ideias clausewitzianas que podem ser vinculadas às concepções kantianas seriam: a violência presente na guerra (estética); guerra absoluta (lógica); acaso e probabilidade (moral). Nesse sentido, qualquer guerra seria sempre permeada pela violência, pois a guerra nada mais é que um fenômeno no qual a violência é empregada em grande escala, é universal e categórico, "[...] e assim o é, principalmente, porque está abrigado pelo senso comum e pela História." (Alves, 2006: 19). Este autor destacou a concepção de Clausewitz sobre a violência: “[...] a solução sangrenta da crise, o esforço para a destruição da força inimiga, é o filho primogênito da guerra [...]" (Alves, 2006: 19). A acepção de guerra absoluta também conta com a presença da violência, mais do que isso, ela é o início, o meio e fim deste tipo de guerra. A lógica da guerra é dada pelo fato de que a violência leva a guerra ao extremo a partir de três situações: a busca da destruição recíproca; a ação ininterrupta em busca da eliminação do oponente e máximo emprego de meios e de força de vontade.

O acaso e a probabilidade são manobrados por coragem e talento e dependem, portanto, das qualidades pessoais do comandante e das forças em combate. Assim, podemos concluir que a relação teórica proposta pelo tenente-coronel Alves (2006), entre e Kant e Clausewitz se produziu através dos seguintes conceitos: Estética - violência; Lógica - a tendência ao extremo; Moral - acaso e probabilidade. $\mathrm{O}$ autor frisou ainda que a grande importância de Kant para Clausewitz foi a inspiração para a construção das concepções subjetivas do prussiano, característica do idealismo alemão.
A última vinculação filosófica feita por Alves foi entre Thomas Hobbes (1588-1679) e Clausewitz. Dois elos são possíveis entre os autores supracitados: o primeiro diz respeito ao "[...] caráter subalterno da guerra e o segundo é relativo à influência da sensibilidade [...]" (Alves, 2006: 21). Thomas Hobbes afirmou na obra Leviatã (1961) que a condição natural do homem é a "guerra de todos contra todos", determinada pela competição, desconfiança e glória. E o que poderia "frear" tal condição humana? Hobbes concluiu que era necessário um contrato social que viabilizasse a existência da harmonia social entre os homens. Para o brasileiro, esta ideia hobbesiana influiu profundamente na alocação da política na teoria clausewitziana, que atuaria como "[...] um elemento moderador para controlar a insensatez do curso natural da guerra" (Alves, 2006: 20).

$\mathrm{O}$ segundo elo entre Hobbes e Clausewitz diz respeito às paixões hobbesianas, que na concepção clausewitziana são os fatores morais da guerra. Ao ver do tenente-coronel Alves (2006), as definições de guerra para os dois autores deixa evidente a relação entre os termos. Hobbes apostou na guerra como um fenômeno competitivo entre os homens na busca pela igualdade. Já Clausewitz viu a guerra pelo prisma do ódio, que leva os homens a se enfrentarem violentamente. $\mathrm{O}$ conceito de Hobbes, literalmente:

A guerra, um comportamento competitivo, é decorrente de uma paixão humana - a esperança - que por sua vez, é determinada por uma circunstância básica e natural dos homens: a igualdade. (Alves, 2006: 20).

Após apresentar a percepção de guerra para Hobbes, Alves a relacionou com a ideia de Clausewitz:

A guerra - que implica necessariamente derramamento de sangue - é decorrente da paixão humana - o ódio - que, por sua vez, é determinada por circunstância básica e natural dos homens: violência. (Alves, 2006: 20-21).

Ao ver de Alves (2006), a relação entre os dois autores é clara e consistente, e, possivelmente, Hobbes teve uma influência significativa sobre o pensamento complexo de Clausewitz.

O texto analisado constitui uma exceção na produção militar brasileira sobre Clausewitz. Nesse sentido, "Por que Clausewitz é considerado um filósofo da guerra" nos pareceu um dos textos mais bem estruturados entre os militares do Exército brasileiro no período pós-Guerra Fria, uma vez que o autor não se ancorou somente em um conceito clausewitziano, mas quis demonstrar a grandeza de Da Guerra. Concordamos com o autor que ressaltou a escassez de trabalhos que abordam, em um nível 
mais aprofundado, a teoria do general prussiano no meio militar brasileiro.

\section{Considerações Finais}

Clausewitz foi muito mais citado do que lido, eis a premissa que guiou este artigo. Observamos que Clausewitz obteve distintos comentários acerca de sua teoria, motivados pelas conjunturas históricas de conflitos e pelas interpretações pessoais de militares e teóricos da área estratégica. Notamos a ascensão e queda da influência de Clausewitz entre as duas Guerras Mundiais e a Guerra Fria e, a discussão de sua atualidade ou obsolescência no pós-Guerra Fria. Este foi o debate acerca de Clausewitz em alguns países do Ocidente - Alemanha, França, Estados Unidos e Inglaterra - mas, e no Brasil, como teriam se apropriado os militares pertencentes ao Exército brasileiro da teoria clausewitziana? Escolhemos a Força Terrestre devido à relação estreita de Clausewitz com as guerras terrestres. Para responder a tal indagação buscamos a recepção de Clausewitz no Brasil no período do pós-Guerra Fria, quando a discussão da validade da teoria clausewitziana para os novos conflitos se acirrava entre militares e acadêmicos.

Tentamos compreender neste artigo a interpretação que os militares brasileiros deram ao conceito central da teoria clausewitziana, a trindade da guerra. Alcançamos duas percepções quanto à utilização desta concepção: influência da conjuntura e leitura enviesada do autor. A conjuntura vivida - transformações estratégicas, novo papel das Forças Armadas, probabilidade de interferência estrangeira na Amazônia - marcou a interpretação e utilização dos militares brasileiros quanto à teoria clausewitziana. A trindade da guerra foi mal compreendida pelos militares brasileiros, que repetiram o erro de inverter o conceito clausewitziano, afirmando que é a trindade é representada pelos elementos - povo, exército e governo -, enquanto a verdadeira trindade clausewitziana é embasada em três forças que agem no interior de qualquer guerra: violência, o acaso e a probabilidade, instrumentalidade da política. Observa-se nas leituras brasileiras sobre a trindade a influência da visão de Mary Kaldor, Martin van Creveld, Collin Powell e Harry Summers Júnior, indivíduos que propagaram a deturpação da trindade de Clausewitz.

Acreditamos na importância e atualidade dos pensamentos de Clausewitz e ansiamos por uma ampliação e fortalecimento no relacionamento entre o prussiano e os militares brasileiros, no qual os conceitos deste sejam melhores compreendidos e analisados. Ainda observamos que se faz necessário que Clausewitz seja compreendido a partir da conjuntura histórica na qual estava inserido, da Revolução Francesa, das batalhas napoleônicas, das intensas transformações políticas, econômicas e sociais pelas quais passavam as sociedades europeias. A fim de que Clausewitz não tenha mais os seus pensamentos deturpados é indispensável uma leitura profunda de suas obras, sobretudo, Da Guerra e, uma análise minuciosa do contexto histórico no qual este viveu.

\section{Referências}

Almeida, Nelson O' de. 1989. Forças Armadas: apenas segurança externa? A Defesa Nacional, (742): 23-34.

Alves, Leonardo Ramalho Rodrigues. 2006. Por que Clausewitz é considerado um filósofo da guerra? A Defesa Nacional, (805): 15-21.

Alves, Vágner Camilo. 2007. O poder militar norteamericano e o panorama estratégico pós-Guerra Fria. Rio de Janeiro, Conferência Nacional de Política Externa e Política Internacional, v. 2, série III.

Aron, Raymond. 1986. Pensar a guerra, Clausewitz: a era europeia. Brasília: Editora Universidade de Brasília.

Bassford, Chistopher. 1994. Clausewitz in English: the reception of Clausewitz in Britain and American, 1815-1945. New York: Oxford University Press. PMCid:PMC205515.

Bassford, Christopher e Villacres, Edward. 1995. Reclaiming the Clausewitzian Trinity. Autunm: Parameters.

Bassford, Christopher. 1993. Jomini and Clausewitz: their interaction. $23^{\circ}$ Meeting of the Consortium on Revolucionary Europe.

Bertazzo, Juliana. 2007. A nova agenda internacional de segurança põe a democracia brasileira em risco? Revista Brasileira de Política Internacional, 2(50): 25-41.

Castro Santos, Maria Helena de. 2004. A nova missão das Forças Armadas Latino-Americanas no mundo pós-Guerra Fria: o caso do Brasil. Revista Brasileira de Ciências Sociais, 19(54): 115-128. http://dx.doi. org/10.1590/S0102-69092004000100007

Clausewitz, Carl von. 1979. Da Guerra. São Paulo: Martins Fontes.

Creveld, Martin Van. 1991. The transformation of war. New York: The Free Press.

Fuller, John Frederick Charles. 2002. A Conduta da Guerra. Rio de Janeiro: Biblioteca do Exército Editora.

Hart, Basil Liddell. 1933. The Ghost of Napoleon. Londres: Faber \& Faber.

Howard, Michael. 1983. Clausewitz. Oxford: Oxford University Press. 
Huntington, Samuel. 1996. O Soldado e o Estado: Teoria e Política das Relações entre Civis e Militares. Rio de Janeiro: Biblioteca do Exército.

Jomini, Antoine-Henri. 1840. Précis de l'art de la guerre. Bruxelles: Librairie Militaire de J. B Petit.

Kaldor, Mary. 1999. New and Old Wars. Stanford: Stanford University Press.

Martelo, David. 2009. Estudo Introdutório. In A-H. Jomini, Compêndio da Arte da Guerra. Lisboa: Edições Sílabo.

Martins Filho, João Roberto. 2003. A visão militar sobre as "novas ameaças" no cenário da Amazônia brasileira. In E. J. Lopez, Novas ameaças: dimensões e perspectivas: desafios para a cooperação em defesa entre Brasil e Argentina. São Paulo: Sicurezza.

Martins Filho, João Roberto. 2000. O governo Fernando Henrique e as Forças Armadas: um passo a frente, dois passos atrás. Revista Olhar, (4):1-17.

Paret, Peter. 2001. Clausewitz. In P. Paret (ed.), Construtores da Estratégia Moderna: de Maquiavel à era nuclear. Rio de Janeiro: Biblioteca do Exército Editora.

Paret, Peter e Howard, Michael. 1976. On War. Princeton: Princeton University Press.
Pedrosa, Fernando Vêloso Gomes. 1999. Os desafios da paz, as Forças Armadas e os conflitos do futuro. A Defesa Nacional, (785):108-115.

Powell, Colin e Persico, Joseph. 1995. My American Journey. Nova York: Random House.

Schneider, Fernand. 1975. História das Doutrinas Militares. São Paulo: Difusão Editorial.

Shy, John. 2001. Jomini. In P. Paret (ed.), Construtores da Estratégia Moderna: de Maquiavel à era nuclear. Rio de Janeiro: Biblioteca do Exército Editora. PMCid:PMC2150845.

Silva, Carlos Alberto Pinto. 1992. A estratégia indireta, a guerra irregular e a defesa da Amazônia. A Defesa Nacional, (756):85-89.

Silva, Carlos Eduardo de Melo Viegas da. 2003. A transformação da guerra na passagem do século XXI. Um estudo sobre a atualidade do paradigma de Clausewitz. Dissertação de Mestrado, Universidade Federal de São Carlos.

Strachan, Hew. 2008. Sobre a guerra de Clausewitz. Rio de Janeiro: Jorge Zahar.

Summers, Harry. 1983. Clausewitz and Strategy Today. Naval War College Review, 36: 40-46. 